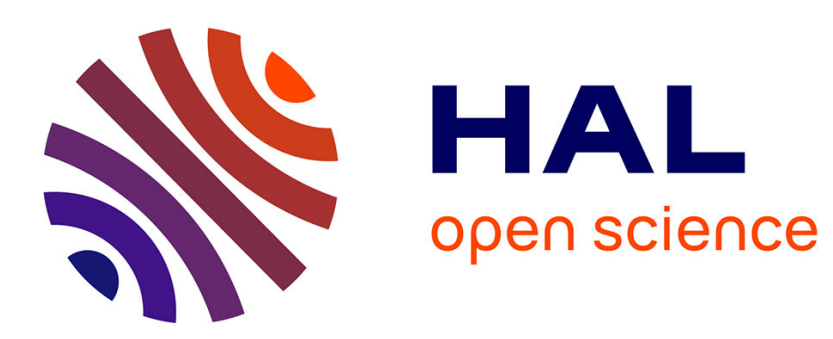

\title{
Has North Africa turned too warm for a Mediterranean forest pest because of climate change?
} Asma Bourougaaoui, Mohamed L Ben Jamâa, Christelle Robinet

\section{To cite this version:}

Asma Bourougaaoui, Mohamed L Ben Jamâa, Christelle Robinet. Has North Africa turned too warm for a Mediterranean forest pest because of climate change?. Climatic Change, 2021, 165 (3-4), pp.46. 10.1007/s10584-021-03077-1 . hal-03196306

\section{HAL Id: hal-03196306 https://hal.science/hal-03196306}

Submitted on 12 Apr 2021

HAL is a multi-disciplinary open access archive for the deposit and dissemination of scientific research documents, whether they are published or not. The documents may come from teaching and research institutions in France or abroad, or from public or private research centers.
L'archive ouverte pluridisciplinaire HAL, est destinée au dépôt et à la diffusion de documents scientifiques de niveau recherche, publiés ou non, émanant des établissements d'enseignement et de recherche français ou étrangers, des laboratoires publics ou privés. 

0

.

\title{
Has North Africa turned too warm for a Mediterranean forest pest because of climate change?
}

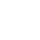

\author{
Asma BOUROUGAAOUI ${ }^{1,2,3}$, Mohamed L. BEN JAMAA ${ }^{1}$, Christelle ROBINET ${ }^{3^{*}}$
}

${ }^{1}$ Institut National de Recherches en Génie Rural, Eaux et Forêts-Laboratoire de gestion et de valorisation des ressources forestières, Ariana, Tunisia

${ }^{2}$ Institut National Agronomique de Tunis, Tunis, Tunisia

${ }^{3}$ INRAE, Unité de Recherche de Zoologie Forestière (URZF), FR-45075 Orléans, France

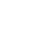

Number of tables: 4

\section{Number of figures: 6}

Number of words (inclusive of all text, references, figures and tables): 10228

\section{Supplementary Material: 1}

Journal: Climatic Change

Type of paper: Original Research Article

Running title: Climate turned too warm for a Mediterranean pest 
22

\section{Abstract}

Climate warming is inducing dramatic changes in species distribution. While many studies report the poleward range expansion of some species, some others report the range retraction and extinction risk of other species. Here we explore how climate warming affects the southern edge in North Africa of the pine processionary moth, Thaumetopoea pityocampa, which is a model insect currently expanding northwards and toward higher elevation in Europe. This Mediterranean forest insect was found in southern Tunisia until 2003. Field surveys were conducted to map the current southern edge of the species in Tunisia. Pheromone traps were installed on a north-south gradient, a translocation experiment of egg-masses was conducted on this gradient and local temperature change was analysed. We thus proved that the pine processionary moth has disappeared from southern Tunisia, and that no more adult males were actually flying there. We also found a decrease of egg-hatching and of the proportion of individuals able to reach larval stages along this gradient, while daily minimal and maximal temperatures globally increased. Furthermore, we showed that daily maximal and minimal temperatures as well as indices of extremely high temperatures have substantially increased during the study period (1980-2019). This study reveals the retraction of the pine processionary moth from southern Tunisia due to higher mortality rates that could be attributed to a significant local warming. The role of other factors (mainly the response of host trees and natural enemies to climate change) may amplify this direct effect and should be further explored.

Keywords: pine processionary moth; Thaumetopoea pityocampa; climate warming; range retraction; Pinus; Tunisia 


\section{Introduction}

Climate change is currently evidencing an unequivocally increase in temperature with an average warming of $0.85^{\circ} \mathrm{C}$ during the period $1880-2012$ (IPCC 2014). Extreme weather events, notably heatwaves, have also increased in both intensity and frequency in most parts of the world since 1950, and in particular in North Africa. For instance, in Tunisia, the mean annual temperature has increased by $1.4^{\circ} \mathrm{C}$ in the $20^{\text {th }}$ century and the increase has even reached $+3^{\circ} \mathrm{C}$ locally in Tunis (northern Tunisia)(Verner et al. 2013). Climate warming is significant throughout Tunisia, even in southern regions where average maximum temperatures can already exceed $40^{\circ} \mathrm{C}$ (Verner et al. 2013). Climate change scenarios suggest that maximal temperature could further rise, for instance by 2.5-3.3 $3^{\circ} \mathrm{C}$ in Tunis by the 2080 s (Verner et al. 2013).

Higher temperatures and more frequent and intense heatwaves threaten lives as well as ecosystems (Parmesan et al. 2000). Indeed, a consequence of the ongoing global warming is a set of dramatic impacts on a broad range of organisms, particularly plants and invertebrates (Parmesan and Yohe 2003; Robinet and Roques 2010; Walther et al. 2002). One of these impacts is the distributional change for species whose geographic range is mainly limited by temperature. Until recently, most of the studies have reported that many species were expanding their distribution toward the poles and higher elevations due to climate change (Andersen et al. 2019; Parmesan et al. 1999; Thomas and Lennon 1999). Few species-level extinctions were reported so far, namely species of anurans including the golden toad (Bufo periglenes) (e.g., Pounds et al. 1999) but, following species distribution models, Thomas et al. (2004) estimated that 15-37\% of the studied species (Taxa of mammals, birds, frogs, reptiles, butterflies, other invertebrates and plants) could become extinct by 2050. The extinction risk is actually predicted to accelerate with the temperature increase, and up to one species out of six could become extinct in the worst climate change scenario (RCP8.5; $4.3^{\circ} \mathrm{C}$ rise compared to pre-industrial temperatures) (Urban 2015). The overall positive or negative impacts of climate change on species distribution are thus very difficult to predict. It is notably unclear how the southern range is impacted for species that move their northern range limit northwards (e.g. southern pine beetle, Dendroctonus frontalis, in the United-States, Lesk et al. 2017, or the pine processionnary moth, Thaumetopoea pityocampa, in Europe, Battisti et al. 2005). Modeling techniques such as species distribution models or phenological models can be used to predict insect distributions and thus assess the potential shifts of northern and southern limits (e.g., for the spruce budworm, Choristoneura fumiferana, in North America, Régnière et al. 2012). However, the southern limit is often not studied in the field and we have so far poor biological evidence to say whether 
some species face a real range expansion (e.g., the northern limit shifts northwards and the southern limit remains the same) or instead a range shift (i.e., both northern and southern limits shift northwards at about the same rate).

The pine processionary moth (PPM), Thaumetopoea pityocampa, is a well-known Mediterranean species that has been recognized by the Intergovernmental Panel on Climate Change (IPCC) to be one of the few species for which the underlying mechanism of response to climate warming was clearly demonstrated (Rosenzweig et al. 2007). Indeed, PPM is expanding northwards in Europe as an indirect effect of the rise of minimal temperatures on insect survival during the cold season (Battisti et al. 2005; Robinet et al. 2007). The northern edge of its distribution has then been considered as an indicator of global warming in France (French Ministry of Ecology, ONERC 2010).

PPM is distributed not only in Southern Europe but also in Asia Minor and North Africa (Roques et al. 2015), where summer temperatures can reach extremely high values. PPM occurrence has been documented at its southern edge in North Africa (Roques et al. 2015) but the effect of climate change on the PPM distribution edge is unclear. PPM has expanded its distribution in the south of Algeria because of the massive pine planting program, The Green Dam, to combat desertification. Climate conditions were likely suitable for the PPM establishment before these pine plantations. In Morocco, PPM has also spread due to large afforestation activities and introduction of exotic pine species. In addition, its southern limit is blurred by its altitudinal limit in the High Atlas. In Tunisia, no large afforestation was done since the 1990s and no mountainous barrier may limit the southern range of PPM. Thus, it offers a unique place to investigate the effects of climate change on the species' southern distribution. PPM had been seen in southern Tunisia until 2003 (Azizi 2015). However, since 2014, PPM has not been seen in this region during occasional field travels (Ben Jamâa, 2017), and it is unclear whether PPM is still present. Since monthly maximal temperatures above $25^{\circ} \mathrm{C}$ are detrimental for PPM populations (Démolin and Rive 1968; Robinet et al. 2015), and maximal temperatures usually exceed $40^{\circ} \mathrm{C}$ in July and August in southern Tunisia, the effects of their rise on these southern PPM populations are questioned.

In this context, two major objectives for this study were: 1) to update our knowledge about the PPM spatial distribution at its southern edge in Tunisia, and 2) to determine the effects of climate change on this possible distribution retraction. For this purpose, we first surveyed the current southern distribution of PPM. We installed pheromone traps to test the presence/absence of adult males, and we installed PPM colonies on a latitudinal gradient to measure their survival rate in relation with weather conditions. We also analyzed long time-series of temperatures along this gradient to characterize locally the intensity of observed climate change. This study on a model species known to 
expand northwards provides the first clear evidence about adverse effects of climate warming on its southern range.

\section{Materials and methods}

\subsection{Study species}

The pine processionary moth (PPM), T. pityocampa (Denis \& Schiffermüller) (Lepidoptera, Notodontidae), is a univoltine forest insect species largely distributed in Mediterranean countries (Démolin 1969; Roques 2015). In Tunisia, adults generally fly in summer from $15^{\text {th }}$ July to $1^{\text {st }}$ August at high altitudes, and from $10^{\text {th }}$ August to $7^{\text {th }}$ September at mid-altitudes (Démolin et al.1968; Ben Jamâa et al. 1999). Females lay eggs on pine needles, larvae hatch about one month later and develop in five instars (L1 to L5; generally from autumn to spring), they feed on pine needles and build collectively white silk nests on pine branches during the cold season. At the end of their development, larvae make a procession (occurring from the end of January to March depending on winter severity) to leave the tree and burry in the soil and pupate. In fact, pupation occurs in February in the mountains, whereas it occurs in September and January-February in the regions of coastline. After a flexible period of diapause, adults emerge. Each PPM life-stage has some thermal constraints given the time window at which they are exposed to. For instance, late instar larvae are vulnerable to cold in winter $\left(\angle 0^{\circ} \mathrm{C}\right)$ while eggs and first instar larvae are vulnerable to heat in summer-autumn $\left(>25^{\circ} \mathrm{C}\right.$ ) across its range in Mediterranean countries (Démolin 1969; Robinet et al. 2015). In relation with these constraints, PPM phenology varies across bioclimate regions (i.e., adult emergence and egg hatching occur later in warmer areas, thus young larvae are less exposed to the highest summer temperatures; Huchon and Démolin 1970) and this phenology could furthermore be affected by climate change (Robinet et al. 2015). PPM, which is the most important insect defoliator of pine forests in Mediterranean countries, causes substantial impact on the tree growth (Jacquet et al. 2013). In addition, PPM also causes important allergy risks to humans and animals because larvae can release urticating setae (Battisti et al. 2017). This species is thus not only a good model species to study the effects of climate change but also an important pest in everyday life in forestry and public health. 
The PPM is one of the most serious pests of Aleppo pine forests in Tunisia (Rive 1966) and thus, it has been episodically surveyed in the past. This insect is historically present in all pine stands from north to south (Démolin and Rive 1968; Roques et al. 2015) (Fig. 1B). First, Démolin et al. (1968) conducted surveys to determine the potential dates of adult emergence across different localities. This dataset can be used to have PPM occurrence points in the 1960s (Fig. SM1-A). In the 1990s, PPM nests have been seen in three regions (Jebel Sidi Driss, Jebel Toual and Techine) around Gabes according to forestry technicians (Fig. SM1-B). Later, PPM occurrence was studied through egg-masses sampled by INRGREF in September-October 1992, 1993 and 1995 throughout different localities going from northern regions to the southernmost edge of natural Aleppo pine stands (Kasserine) (Fig. SM1-B). Thereafter, PPM nests have been last seen in Tataouine in 2003 (Azizi 2015) during field travels in Jebel Brourmet (Fig. SM1-C). In 2010, its presence can be inferred from egg-masses collected by INRGREF, and in 2013-2014 through field surveys conducted by Azizi (2015) (Fig. SM1-C). PPM absence was firstly assessed in 2013-2014 in Tataouine, Gabes and Medenine (Azizi 2015).

\subsection{Mapping the southern edge of the PPM distribution in Tunisia}

Due to characteristic signs of PPM presence (white silk nests, egg-masses, or signs of pine tree defoliation), the presence of PPM is relatively easy to detect on the field. However, recording locations of PPM presence was not enough to map the southern edge of the PPM distribution. We needed to record locations where PPM was absent as well in order to actually define the border. The mapping of PPM northern distribution in France has been standardized over a regular cell grid at a spatial resolution of $8 \mathrm{~km} \times 8 \mathrm{~km}$ (see protocol for field sampling described by Rousselet et al. 2013). We tried to derive a similar approach to map the southern edge of the PPM distribution in Tunisia. However, it was difficult, if not impossible, to adapt this protocol since we had no baseline edge to rely on, and host trees could be very scarce and scattered in southern Tunisia. Therefore, we adopted an intermediate protocol: we reported the occurrence (presence/absence) of the PPM in potentially critical areas. In 2018 , from the $2^{\text {nd }}$ to the $4^{\text {th }}$ of January, we visited the regions supposed to be at the southern edge or beyond (near Sidi Bouzid, Gabes and Tataouine; Fig. 1-2). We notably surveyed areas where pine stands were reported by the General Direction of Forests in Tunis (Fig. 2A), and the main roads along which some isolated pine trees could eventually be found. Trees outside forests could effectively play an important role in habitat connectivity and the presence of the PPM (Rossi et al. 2016). In addition to this extensive survey, we added observations done on October $10^{\text {th }}, 2017$ near Gafsa during a preliminary survey trip. 


\subsection{Pheromone trapping}

181

182

183

184

185

186

187

188

189

190

191

192

193

194

195

196

197

198

199

200

201

202

203

204

205

206

207

208

209

210

211

212

Sexual pheromone traps (BuxaTrap ${ }^{\circledR}$ ) were installed at different dates in summer 2018 as PPM adults generally fly later in warmer areas (Huchon and Démolin 1970). These traps were distributed on a latitudinal gradient going from north to south: Tunis, Testour, Kef, Sidi Bouzid, Gabes and Tataouine (Fig. 1). One to three traps per site were attached on the branches of Aleppo pine trees, Pinus halepensis, placed at 1.5 meter high, and checked weekly until the trap removal (end of September to end of October 2018). When several traps were installed on the same site, they were distant to 50 meters from each other.

\subsection{Translocation of egg masses}

General method. In order to assess the mortality rate under different bioclimatic zones, we chose to work on a thermal gradient consisting of three locations (with Aleppo pines): Zaghouan (core area), Sidi Bouzid (supposedly on the southern edge) and Tataouine (from where PPM may have disappeared) (Fig. 1). Since early larval stages are particularly sensitive to high temperatures (Robinet et al. 2015), we aimed to measure how maximal temperatures recorded in Tunisia in autumn could impact the survival of eggs and early larval stages. Some PPM colonies were thus translocated and exposed to field weather conditions from September 2019 to January-February 2020 on this gradient. Then, they were retrieved before they left their nest (e.g., just before the end of their larval development and the processions). In this way, we avoid their potential establishment in the area where it has likely disappeared (even if the establishment risk was supposedly very low). This experiment was inspired from those done in France and Italy to explore the effects of low winter temperatures on the PPM survival at its northern and altitudinal edge (Battisti et al. 2005).

Field experiment in more details. Egg-masses were collected on P. halepensis near Sidi Bouzid on September $17^{\text {th }}, 2019$ (i.e., as soon as egg-masses could be found in this site). The translocation of egg-masses was done on a latitudinal gradient, going from north (Zaghouan, within the PPM core distribution) to south (Tataouine, where PPM has likely disappeared), with an intermediate location at its southern limit (Sidi Bouzid) (Fig. 1). Our initial objective was to translocate 30 egg-masses at each location, but given the low population density, it was not possible and we decided to keep only 30 egg-masses for Tataouine. A total of 15 egg-masses have been translocated at Zaghouan on Sept $25^{\text {th }}, 2019$ (three egg-masses per pine tree, on five trees), 15 egg-masses at Sidi Bouzid on Sept $17^{\text {th }}$, 2019 (three egg-masses per pine tree, on five trees), and 30 egg-masses have been translocated at Tataouine on Sept $18^{\text {th }}, 2019$ (five egg-masses per pine tree, on six trees). Since a very low number of pine trees were available for this experiment, we had to place more egg-masses per tree (five instead 
of three). Egg-masses and nests were then collected on Jan $7^{\text {th }}, 2020$ from Tataouine and Sidi Bouzid, and on Feb $5^{\text {th }}, 2020$ from Zaghouan.

Analysis of egg-masses and nests collected from field experiments. Egg-masses and nests retrieved from the previous experiments were brought to the laboratory at INRGREF (Tunis) and kept at ambient air temperature $\left(25 \pm 2^{\circ} \mathrm{C}\right)$. For each egg-mass, scales covering the eggs were removed to count eggs and split them into four categories (Tsankov et al. 1996; Imbert 2012) following their observation under a binocular magnifier:

(1) hatched eggs, presenting a characteristic large and round larval emergence hole,

(2) non-hatched-eggs, having no larval nor parasitoid emergence holes,

(3) parasitized eggs, showing a characteristic small parasitoid emergence hole and/or having a dead parasitoid inside, and/or having a characteristic parasitoid meconium inside, and finally

(4) other eggs, including dried, flat and non viable eggs, and dead PPM larva that failed to emerge and showed an irregular larval emergence hole.

For each nest, all the living and dead larvae were counted, and their larval instar was determined.

Temperature records. Small data loggers (iButtons ${ }^{\circledR}$ ) have been installed on the three locations from Dec $18^{\text {th }}, 2018$ to Jan $7^{\text {th }}, 2020$ in Tatatouine, from Jan $9^{\text {th }}, 2019$ to Jan $7^{\text {th }}, 2020$ in Sidi Bouzid and from Feb $2^{\text {nd }}, 2019$ to Feb $5^{\text {th }}, 2020$ in Zaghouan to record temperature every two hours. Each logger was attached in the shade of a branch of the selected pine tree among trees used for the translocation experiment. On each location, several temperature statistics were calculated to compare weather conditions: (1) monthly statistics: absolute minimal and maximal temperatures of each month, and mean temperature of each month, and (2) daily statistics: daily minimal and maximal temperatures, and daily mean temperature. Data analysis was done using the $R$ software $(R$ Core Team, 2018).

\subsection{Statistical analysis related to the translocation experiments}

As the percentages of the different egg categories and the living/dead larvae were not normally distributed, a Kruskal-Wallis $\mathrm{H}$ test (followed by a post-hoc Dunn's pairwise tests if the K-W test was significant) was performed to compare the results from the different studied locations. A pairwise Wilcoxon signed Rank test was applied to compare temperatures among the locations of the latitudinal gradient.

\subsection{Analysis of climate data}


Climate data source. Daily minimal and maximal temperatures were kindly provided by the National Institute of Meteorology (INM) in Tunis at the following stations: (1) Mograne (representative of the weather in Zaghouan, located $6.7 \mathrm{~km}$ away) during the period 1991 - 2011, (2) Medenine (located at $47.6 \mathrm{~km}$ from Tataouine, characterized by desert climate as the latter) during the period $1980-2011$, (3) Sidi Bouzid during the period 1980 - 2014, and (4) Tunis during the period $1980-2014$. Hereafter, for simplification, we will refer to the name of experimental sites: Zaghouan for the Mograne weather station, and Tataouine for the Medenine weather station. Since these datasets had missing data and do not provide recent weather conditions (between 2011 or 2014 to 2019), we also retrieved daily temperatures from Tutiempo Network (https://fr.tutiempo.net/climat/tunisie.html). For the four stations, we checked that there was a good agreement between the two datasets (i.e., we compared daily temperatures in 2011 and they correctly matched). We thus considered the combination of these two datasets to have full timeseries without missing data until 2019.

Calculation of annual maximal, minimal and mean temperatures. To explore the local warming trend during the period 1980-2019 in Tunis, Sidi Bouzid and Tataouine and during the period 1991-2019 in Zaghouan, we calculated the annual mean of daily maximal, minimal and mean temperatures (Tmax, Tmin, and Tmean, respectively). Then, we made a linear regression for each variable (Tmax, Tmin, Tmean) as a function of the years to elucidate the magnitude of warming on each site. These analyses were performed using R software (R Core Team 2018).

Calculation of indices of extreme temperatures. Nine indices related to temperatures from those defined by the Expert Team on climate change Detection Monitoring and Indices (ETCCDMI) were considered (Table 1; Peterson 2005; Zhang and Yang 2004).The calculation of these indices as well as statistical analyses were performed using the RclimDex package of $R$ software (https://github.com/ECCC-CDAS/RClimDex). Slopes of the annual trends of these extreme climate indices were calculated based on a least square linear fitting. A locally weighted linear regression using a loess smoother function in R (Zhang and Yang 2004) was also applied to each index. The statistical significance of trends was assessed based on the Student's t-test for the estimate of the slope at the $95 \%$ level ( $p$ value $<0.05$ ). In addition to these annual trends, we explored on a monthly basis (from June to October) the fluctuation of the number of days at which daily maximal temperature exceeded 35 and $40^{\circ} \mathrm{C}$.

\section{Results}




\subsection{Mapping the PPM southern edge in Tunisia}

In total, 186 locations were investigated. PPM was found in 25 locations (including one location visited in 2017 in north-east Gafsa) and absent in 161 locations (including one location visited in 2017 in south-east Gafsa) (Fig. 2B). All the southern sites visited around Gabes and Tataouine were free from PPM, whereas the most southern sites infested by PPM were the north-east of Gafsa and south-east of Sidi Bouzid.

\subsection{Pheromone trapping}

No PPM male adult was caught in the pheromone traps in Gabes and Tataouine, thus confirming that PPM is absent in the most southern sites. In contrast, 40-58 adults per trap were caught in the regions of Sidi Bouzid, Kef (wherein the highest number of captures occurred), Testour and Tunis (Table 2).

\subsection{Translocation of egg masses}

Comparison of hatched eggs. The proportion of hatched eggs clearly decreased from north to south (gradient Zaghouan - Sidi Bouzid - Tataouine) (Fig. 3; Tables SM2-SM4). In addition, in Tataouine, one whole egg-mass out of $30(3 \%)$ has not hatched, whereas all egg-masses from Sidi Bouzid and Zaghouan provided some hatched eggs (Tables SM2SM4). There was a statistically significant difference in the percentage of hatched (Kruskal-Wallis $X^{2}=7.06, \mathrm{df}=2, \mathrm{P}=0.029$ ) and unhatched eggs (Kruskal-Wallis $X^{2}=12.19, \mathrm{df}=2, \mathrm{P}=0.002$ ) between the different locations. There was a significant difference in hatched eggs between Tatatouine and Zaghouan (Dunn's pairwise test; $P=0.028$, adjusted using the Bonferroni correction), and there was a significant difference in unhatched eggs, between Tatatouine and Zaghouan ( $P=0.003$, adjusted by the Bonferroni correction), and between Sidi Bouzid and Zaghouan ( $P=0.012$, adjusted by the Bonferroni correction).

Comparison of parasitized eggs and other mortality factors. Surprisingly the rate of parasitized eggs was higher in Tataouine, including both the generalist egg parasitoids, Ooencyrtus pityocampae, and the supposedly specialist egg parasitoids, Baryscapus servadeii, and most of parasitoids survived and emerged because we found parasitoid meconium more than dead parasitoids inside eggs. Nevertheless, this parasitism rate was very low (6\% on average) and did not vary significantly from the other regions $\left(X^{2}=1.67, d f=2, P=0.433\right)$. Other factors of egg mortality had little impacts (less 
than $11.5 \%$ on average) and did not show any clear pattern on the latitudinal gradient. The percentage of other egg mortality was not significantly different among locations $\left(X^{2}=0.35, d f=2\right.$, $\mathrm{P}=0.836)$.

Comparison of larval survival. Unfortunately, when we retrieved PPM nests, none of them was found on the site of Zaghouan (they were likely removed by people). As a result, we could only compare larval survival between Sidi Bouzid and Tataouine. The proportion of living larvae was lower in Tataouine than in Sidi Bouzid (Fig. 3; Tables SM2-SM4). Surprisingly a few larvae succeeded to survive in Tataouine ( $46 \%$ of eggs succeeded their development in larvae). The percentage of larvae that succeeded to survive was not significantly different between Tataouine and Sidi Bouzid $\left(X^{2}=0.83\right.$, $d f=1, P=0.361$ ). However, the percentage of dead larvae was significantly higher in Tataouine (12\%) than in Sidi Bouzid $\left(X^{2}=4.03, d f=1, P=0.04\right)$. The highest larval mortality affected mainly young instars (L2 and L3) in Tataouine (table SM2). Besides, larval development was relatively faster in Tataouine compared to Sidi Bouzid. Percentages of $L 2, L 3, L 4$ and $L 5$ instars were respectively 11 versus 18\%, 41 versus 54\%, 41 versus $27 \%$ and 7 versus 1\% in Tataouine compared to Sidi Bouzid (Tables SM2 and SM3).

Comparison of temperatures. Temperatures globally increased from north to south (gradient Zaghouan - Sidi Bouzid - Tataouine) (Fig. 4). The average from Sept $1^{\text {st }} 2019$ to Feb $5^{\text {th }} 2020$ of daily minimal, mean and maximal temperatures was: $15.1^{\circ} \mathrm{C}, 20.1^{\circ} \mathrm{C}$ and $26.5^{\circ} \mathrm{C}$ in Tataouine; $14.3^{\circ} \mathrm{C}$, 19.0 $0^{\circ} \mathrm{C}$ and $26.0^{\circ} \mathrm{C}$ in Sidi Bouzid, and $11.7^{\circ} \mathrm{C}, 16.1^{\circ} \mathrm{C}$ and $24.0^{\circ} \mathrm{C}$ in Zaghouan. Daily minimal and mean temperatures were significantly different among the three locations $\left(P<10^{-4}\right.$ and $\left.P<10^{-9}\right)$, while the maximal daily temperature was significantly different only between Tataouine and Zaghouan $(P=0.005)$, and Sidi Bouzid and Zaghouan $(P=0.02)$ but not between Tataouine and Sidi Bouzid $(P=0.33)$ (pairwise Wilcoxon Signed Rank Test) (Fig. 5).

\subsection{Analysis of climate data}

Trends in annual maximal, minimal and mean temperatures. All temperature variables (Tmax, Tmin and Tmean) showed a significant rising trend for all sites (Fig. 6; Table 3). Within 39 years (19802019), maximal temperatures have thus increased by $1.2^{\circ} \mathrm{C}, 1.7^{\circ} \mathrm{C}, 1.2^{\circ} \mathrm{C}$ respectively in Tunis, Sidi Bouzid, Tataouine and they have increased by $0.8^{\circ} \mathrm{C}$ within 28 years (1991-2019) in Zaghouan. Minimal temperatures have increased by $2.6^{\circ} \mathrm{C}, 1.5^{\circ} \mathrm{C}$ and $1.7^{\circ} \mathrm{C}$ within 39 years respectively in Tunis, 
Sidi Bouzid, Tataouine, and they have increased by $2^{\circ} \mathrm{C}$ within 28 years in Zaghouan. The highest annual temperatures are recorded in Tataouine with $\operatorname{Tmax}=28^{\circ} \mathrm{C}, \mathrm{Tmin}=16.5^{\circ} \mathrm{C}$ and $\operatorname{Tmean}=22.5^{\circ} \mathrm{C}$ (Fig. 6).

Trends in extreme temperatures: warm indices. The number of warm nights (TN90p) significantly increased at all the stations (Table 4). Similarly, there was a positive trend on the number of warm days (TX90p) with significant increase observed only at Tunis and Sidi Bouzid. There was a positive trend on TXX at all stations (except Zaghouan, presented a negative insignificant trend) with a significant increase observed at Sidi Bouzid. Trend analysis for TNx showed a positive trend with significant increase throughout the study areas. The other indices (except SU40 and SU35, in Zaghouan) indicated an increasing trend. The number of days with a daily maximal temperature (TX) above $40^{\circ} \mathrm{C}$ (SU40) showed a significant increase at Sidi Bouzid and Tataouine. There was a highly significant increase in the number of days with a daily maximal temperature (TX) above $35^{\circ} \mathrm{C}$ (SU35) at Tunis, Sidi Bouzid and Tataouine. The number of days with a daily maximal temperature (TX) above $25^{\circ} \mathrm{C}$ (SU25) presented a highly significant increase at Tunis, Sidi Bouzid and a significant increase at Tataouine (Fig. SM5-SM7).

Trends in extreme temperatures: temperature fluctuation indices. In diurnal temperature range (DTR), three sites (Tunis, Zaghouan and Tataouine) had significant downward trends (Table 4). The lowest DTR value was recorded in Tunis (in 2004), followed by Zaghouan (in 2018) and Tataouine (in 2017). Unlike the other regions, there was a positive but not significant trend for DTR at Sidi Bouzid.

Number of days with temperatures above $35^{\circ} \mathrm{C}$ and $40^{\circ} \mathrm{C}$ from June to October. Different patterns were observed among months (SM8-SM13). Both Tataouine and Sidi Bouzid recorded extremely high temperatures from June to August, while Tataouine appears to be even warmer than Sidi Bouzid from September to October. Indeed, more than half of July and August months had temperatures higher or equal to $35^{\circ} \mathrm{C}$ in the southern regions (Sidi Bouzid and Tataouine) nearly each year (Fig. SM9 ; Fig. SM10). Similarly, the number of days with temperatures higher or equal to $40^{\circ} \mathrm{C}$ (even exceeded $45^{\circ} \mathrm{C}$ ) was more frequent in the southern regions than the northern ones (SM9-SM10). In September, high temperatures were more frequent in Tataouine (exceeding $35^{\circ} \mathrm{C}$ for $8-20$ days and $40^{\circ} \mathrm{C}$ for 1-8 days ; Fig. SM11) than in other sites. In October, temperatures exceeded frequently $35^{\circ} \mathrm{C}$ (up to 10 days) in Tataouine (Fig. SM12). Although such phenomenon was observed also in the past (in 1990 and 1992), it was less frequent. Recently, several consecutive years reached such high temperatures (at least 4 days above $35^{\circ} \mathrm{C}$ were recorded each year from 2012 to 2016; Fig. SM12). 
Climate change has been demonstrated to be a major factor affecting populations of forest pests in numerous ways. Recent literature has mainly reported species expanding their distribution, such as T. pityocampa (Roques et al. 2015). In this species, range expansion in Europe has been explained by higher winter temperatures and thus more favorable weather conditions to survive in winter. On the other hand, temperature increase and drought may affect the southern edge of the species distribution (in North Africa). Thus, the present study explored the effects of climate warming on possible southern retraction based on experimental approaches conducted in the field.

\subsection{Field evidence of a southern retraction}

382

PPM was historically present in southern Tunisia (the presence was confirmed through the observation of PPM nests), notably in Tataouine (Azizi 2015). Following the survey of the PPM's southern edge, it appears that the PPM was not found neither around Gabes nor Tataouine, whereas it was present in the north-east of Gafsa and south-east of Sidi Bouzid. Pheromone traps confirmed that no PPM males were actually flying in these two areas. Former PPM nests (i.e., nests built the previous year(s)) were not found either. Following these results, we proved that PPM has effectively disappeared from south Tunisia and the reason for this southern retraction has then been explored.

\subsection{Lower survival in warmer southern sites.}

We observed a global decrease of egg hatching and proportion of living larvae (Fig. 3), and an increase of temperatures (Fig. 4) along the latitudinal gradient from north to south. Maximal temperatures as well as egg hatching rates were however not statistically different between the southern PPM edge (Sidi Bouzid) and the area where it has disappeared (Tataouine), but they were different from the northernmost site (Zaghouan) (Fig. 5). Minimal and mean temperatures were though statistically higher in Tataouine than in Sidi Bouzid during the study period (Fig. 5), and thus may not explain the same low level of hatching rates in both Sidi Bouzid and Tataouine. However, it could explain why larval development was substantially faster in Tataouine than in Sidi Bouzid (Tables SM2-SM3). Indeed these higher (minimal and mean) temperatures could trigger a more rapid development since insect development rate is usually linearly correlated to temperature, at least up to an optimal temperature threshold (Rebaudo and Rabhi 2018). Maximal temperatures could be the main driver of the PPM mortality and disappearance in southern Tunisia. If the development rate of eggs increases with increasing mean temperatures, then young larvae hatching from these eggs appear earlier in autumn and are thus likely exposed to higher maximal and potentially lethal 
temperatures. We could thus expect a further retraction from the region of Sidi Bouzid in the coming years if minimal and mean temperatures continue increasing with climate warming. Difficulties in collecting egg-masses in this region provide evidence of the PPM population decline at its current southern edge.

\subsection{Retrospective analysis of the role of local climate warming}

Average annual maximal, mean and minimal temperatures significantly increased between 1980 and 2019 in all investigated sites. Except in Sidi Bouzid, minimal temperatures increased faster than maximal temperatures (Table 3). As already mentioned, increase of minimal temperature is likely beneficial to the development rate of the insect. However, if eggs could develop faster, young larvae would be exposed to higher summer temperatures (due to both their occurrence at an earlier timewindow in the season, and an increase - even if more moderate - of maximal temperatures) and this would potentially foster mortality rates. In Tataouine, given the observed warming trend (Table 3), the annual minimal and maximal temperatures have increased respectively by $0.7^{\circ} \mathrm{C}$ and $0.5^{\circ} \mathrm{C}$ over 16 years (since PPM was observed in 2003), which is a substantial warming. More importantly, extremely high temperature values are recorded more and more often in southern regions (Sidi Bouzid and Tataouine; SU40, SU35, TXX in Table 4). The increasing trend of these heat indices may have a detrimental effect on the early instars larvae and thus contribute to higher mortality rates, which may explain the disappearance of PPM from southern Tunisia. Although we found that some larvae could develop in Tataouine in 2019-2020, maximal temperatures were much lower that year than the previous years (Fig. 6) and heat extremes (e.g., TXX and SU35) were also lower (Fig. SM5). Higher temperatures have mostly been recorded between 2009 and 2016 (Fig. 6).

\subsection{Life-stages potentially impacted by extremely high temperatures}

Looking at summer data more specifically, temperatures usually exceeded $35^{\circ} \mathrm{C}$ on more than 15 days per month, even $40^{\circ} \mathrm{C}$ for a few days, and reached sometimes $45^{\circ} \mathrm{C}$ in the southern regions in July and August (Fig. SM9-SM10). This period corresponds to the flight of adults, which may be subject to lethal temperatures (Ben Jamâa 2017). However, we should note that both Sidi Bouzid and Tatatouine had very similar maximal temperatures in summer (Fig. SM9-SM10). Regarding the autumn data, in September (period that coincides with the beginning of oviposition), temperatures above $35^{\circ} \mathrm{C}$ and $40^{\circ} \mathrm{C}$ were more frequent in Tataouine (Fig. SM11). These temperatures (in September) could negatively affect egg survival if they reach unusually high values. Indeed, Robinet et al. (2013) showed that egg-masses from a French PPM population were able to survive a daily maximal temperature of $40^{\circ} \mathrm{C}$ during 12 consecutive days. However, Rocha et al. (2017) showed that negative effects appeared on egg-masses from a Tunisian PPM population at $42^{\circ} \mathrm{C}$ after only three 
days of heatwaves, and none of them survived at $44^{\circ} \mathrm{C}$. In October (period that corresponds to the development of young larvae), temperatures exceeded $35^{\circ} \mathrm{C}$ (up to 10 days) in Tataouine (Fig. SM12). Young larvae are particularly sensitive to high temperatures (Robinet et al. 2015). First instar larvae from French and Portuguese winter PPM populations have a substantial mortality rate at $36^{\circ} \mathrm{C}$ (Santos et al. 2011). Thus, we suggest that high temperatures recorded especially in autumn in southern Tunisia had contributed to higher mortality rates and to the disappearance of the PPM from this area.

\subsection{Other factors to explore}

Even if the increase of temperatures could be largely involved in the retraction of the PPM southern range, other factors also need to be explored. Firstly, as already briefly mentioned, a change in PPM phenology could also potentially explain changes in its geographical distribution (Robinet et al. 2015) and should be further explored in association with the direct effect of climate warming on PPM survival. Secondly, climate change can also affect the PPM host trees. The last IPCC report (2014) revealed that the frequency and intensity of droughts has likely increased in the Mediterranean areas especially in arid regions. Droughts could considerably reduce the needles' length (Borghetti et al. 1998) and decrease the leaf life span (Girard et al. 2012), and this may disturb the layout of eggmasses around the pine needles. In addition, it is currently unknown whether climate change affects the pine needles' composition and how this change could alter the larval survival. This indirect effect of climate change on host trees could be an additional mortality factor to consider. The effect of drought on host preference and performance was indeed demonstrated for the Mediterranean pine shoot beetle, Tomicus destruens, on maritime pine, Pinus pinaster (Branco et al. 2010). In addition, according to Henriksson et al. (2003), leaf water content is one of the most important factors affecting the growth of defoliating larvae such as Epirrita autumnata. Hence, drought stress may have a detrimental effect on insect performance reflected as decrease in leaf water content, and/or increase in leaf toughness and in secondary metabolites concentration. However, there is little information available regarding the effect of drought on the PPM performance. Thirdly, increase of both droughts and temperatures in most arid conditions would increase $P$. halepensis stress, thus impacting their own growth and survival (Cherif et al. 2019; Vicente-Serrano et al. 2010). In general, phenological plasticity of some tree species (such as Pinus sylvestris in Europe) may not allow the tree species to adapt to climate change at their distributional edge (Duputié et al. 2015). If the PPM host trees would no longer be able to survive in some regions, the PPM would also no longer be able to be there, unless shifting on other hosts. Lastly, another mortality factor to consider is parasitism. Indeed, the rate of parasitized eggs was relatively high in Tataouine (Fig. 3). Although this parasitism rate increases mortality, it is quite low (6\% on average) compared to other parts of the PPM 
471 distribution (e.g. $24.4 \%$ in France (Orléans) and $29 \%$ in Bulgaria (Maglizh), Georgiev et al. 2020) and

472 may not be a key factor in the PPM retraction.

\section{$473 \quad 4.6$ Contrasted effects of climate change on insects' range and outbreaks}

474 Increase of outbreaks and spread of pests are often reported. Bark beetles, for example, can cause 475 tree mortality due to severe droughts, which are amplified by higher temperatures, and this could 476 trigger a positive feedback on the reproductive rate of the insect populations (Raffa et al. 2008; Raffa 477 et al. 2015). In contrast, range reduction and extinction risks are often reported for other species. In 478 Britain, fine-resolution mapping revealed extinction gradients since 1970 for three of the four 479 northern butterfly species: Aricia artaxerxes and Erebia aethiops retracted northwards, and Erebia 480 epiphron retracted uphill (Franco et al. 2006). Actual shifts of insect distribution are poorly 481 documented so far, apart from predictions of bioclimate models. A good example documenting a 482 shift in outbreaks is the larch bud moth, Zeiraphera griseana. Its cyclical outbreaks are actually 483 shifting from medium to high elevations in the Alps, and this could be attributed to a better host484 insect synchronization with climate warming at those high elevations (Johnson et al. 2010; Rozenberg 485 et al. 2020). The study presented in this article, in association with the previous study of Battisti et al. 486 (2005) done on the PPM northern range expansion, thus provides the very first well-documented 487 shift in species distribution due to climate warming, and it also reveals the causal mechanisms.

\subsection{Conclusions}

489 Increase of outbreaks and spread are often reported for some species while range reduction and 490 extinction risks are often reported for other species. The scientific community is usually focusing on 491 what is threatening (e.g., more damages due to pests, or disappearance of protected species), but 492 the overall and comprehensive impact of climate change is not so often explored. Here we 493 demonstrate that climate could become too warm for a Mediterranean forest pest in the south of its 494 distribution. The next question to tackle is whether forest trees that could finally get rid of pests or 495 pathogens could actually persist in such extreme climate conditions. 


\section{Acknowledgments}

497 We are grateful to Jérôme ROUSSELET (INRAE-URZF, Orléans, France) for insightful advice on 498 mapping the edge of species distribution and translocation experiment, to Olfa EZZINE and Samir 499 DHAHRI (INRGREF, Tunis, Tunisia) for general discussions and support in the frame of the PhD of 500 Asma BOUROUGAAOUI, and to Adel BEN ABADA (INRGREF, Tunis, Tunisia) for his valuable help in the 501 field. Pheromone traps and protective suits were kindly provided by Jean Claude MARTIN (INRAE502 UEFM, Avignon, France). The distribution of pine stands was kindly provided by the General Direction 503 of Forests in Tunis, and a part of the temperature datasets by the National Institute of Meteorology 504 (INM) in Tunis. This study was supported by funding from the University of Carthage (Tunisia): the 505 University provided two grants to Asma BOUROUGAAOUI to spend her internships (two 506 months/grant) at INRAE-URZF in France in 2018 and 2019 in the frame of her PhD. It was also 507 supported by the ANR project PHENEC. 


\section{References}

509

510

511

512

513

514

515

516

517

518

519

520

521

522

523

524

525

526

527

528

529

530

531

532

533

534

535

536

537

538

539

540

541

Andersen JC, Havill NP, Mannai Y et al (2019) Identification of winter moth (Operophtera brumata) refugia in North Africa and the Italian Peninsula during the last glacial maximum. Ecol Evol 9:13931-13941. https://doi.org/10.1002/ece3.5830

Azizi Z (2015) Eclaircissement de la situation de la chenille processionnaire du pin dans le sud de sa répartition (le sud Tunisien). Master thesis, Institut National Agronomique de Tunisie, Tunis, Tunisie, pp. 66.

Battisti A, Stastny M, Netherer S et al (2005) Expansion of geographic range in the pine processionary moth caused by increased winter temperatures. Ecol Appl 15:2084-2096. https://doi.org/10.1890/04-1903

Battisti A, Larsson S, Roques A (2017) Processionary Moths and Associated Urtication Risk: Global Change-Driven Effects. Annu Rev Entomol 62:323-342. https://doi.org/10.1146/annurev-ento$\underline{031616-034918}$

Ben Jamâa ML, Jerraya A (1999) Essai de lutte contre la processionnaire du pin : Thaumetopoea pityocampa Schiff. (Lep., Thaumetopoeïdae) à l'aide de Bacollus thuringiensis Kurstaki (ECOTECHPRO). Ann INRF Tunisie 3: 3-12

Ben Jamâa ML (2017) Geographic area of the pine processionary moth (Thaumetopoea pityocampa Schiff, Lepidoptera) in the southern Aleppo pine forests and effect of the climatic change. Paper presented at the 125th IUFRO Anniversary Congress - Book of abstract, Freiburg, page 222. ISBN 978-3-902762-88-7. Available at: http://iufro2017.com/downloads/. Accessed 2 Jul 2020

Borghetti M, Cinnirella S, Magnani F, Saracino A (1998) Impact of long-term drought on xylem embolism and growth in Pinus halepensis Mill. Trees 12:187-195. https://doi.org/10.1007/PL00009709

Branco M, Pereira JS, Mateus E, Tavares C, Paiva MR (2010) Water stress affects Tomicus destruens host pine preference and performance during the shoot feeding phase. Ann For Sci 67:608. https://doi.org/10.1051/forest/201021

Cherif S, Ezzine O, Khouja ML, Nasr Z (2020) Comparison of the physiological responses of three pine species in different bioclimatic zones in Tunisia. Appl Ecol Environ Res 18:1-13. http://dx.doi.org/10.15666/aeer/1801 001013

Démolin G, Rive J (1968) La processionnaire du pin en Tunisie. Ann INRF Tunisie 1:1-19

Démolin G (1969) Bioécologie de la processionnaire du pin, Thaumetopoea pityocampa Schiff. Incidences des facteurs climatiques. Boletin del Servicio de Plagas Forestales:9-24

Duputié A, Rutschmann A, Ronce O, Chuine I (2015) Phenological plasticity will not help all species adapt to climate change. Glob Chang Biol 21:3062-3073. https://doi.org/10.1111/gcb.12914 
Franco AMA, Hill JK, Kitschke C et al (2006) Impacts of climate warming and habitat loss on extinctions at species' low-latitude range boundaries. Glob Chang Biol 12:1545-1553. https://doi.org/10.1111/j.1365-2486.2006.01180.x

Georgiev G, Rousselet J, Laparie M et al (2020) Comparative studies of egg parasitoids of the pine processionary moth (Thaumetopoea pityocampa, Den. \& Schiff.) in historic and expansion areas in France and Bulgaria. Forestry: An International Journal of Forest Research cpaa022.https://doi.org/10.1093/forestry/cpaa022

Girard F, Vennetier M, Guibal F et al (2012) Pinus halepensis Mill. crown development and fruiting declined with repeated drought in Mediterranean France. Eur J For Res 131:919-931. https://doi.org/10.1007/s10342-011-0565-6

Henriksson J, Haukioja E, Ossipov V et al (2003) Effects of host shading on consumption and growth of the geometrid Epirrita autumnata: interactive roles of water, primary and secondary compounds. Oikos 103:3-16. https://doi.org/10.1034/j.1600-0706.2003.12306.x

Huchon H, Démolin G (1970) La bioécologie de la processionnaire du pin. Dispersion potentielle, dispersion actuelle. Revue Forestière Française 151:220-234. https://doi.org/10.4267/2042/20421 Imbert CE (2012) Expansion d'un ravageur forestier sous l'effet du réchauffement climatique : la processionnaire du pin affecte-t-elle la biodiversité entomologique dans les zones nouvellement colonisées ? PhD thesis, Université d'Orléans, Orléans, France. Available at: https://www.theses.fr/162101465. Accessed 29 Jul 2020

IPCC (2014) “Climate Change 2014: Synthesis Report," Contribution of Working Groups I, II and III to the Fifth Assessment Report of the Intergovernmental Panel on Climate Change, eds Core Writing Team, R. K. Pachauri, and L. A. Meyer (Geneva: IPCC), pp. 151. ISBN 978-92-9169-143-2. Available at: https://www.ipcc.ch/report/ar5/syr/. Accessed 29 Jul 2020

Jacquet J-S, Bosc A, O'Grady AP, Jactel H (2013) Pine growth response to processionary moth defoliation across a 40-year chronosequence. FOREST ECOL MANAG 293:29-38. https://doi.org/10.1016/j.foreco.2012.12.003

Johnson DM, Büntgen U, Frank DC et al (2010) Climatic warming disrupts recurrent Alpine insect outbreaks. PNAS USA 107:20576-20581. https://doi.org/10.1073/pnas.1010270107

Lesk C, Coffel E, D'Amato AW et al (2017) Threats to North American forests from southern pine beetle with warming winters. Nat Clim Change 7:713-717. https://doi.org/10.1038/nclimate3375 ONERC (2010) Catalogue des indicateurs du changement climatique, Report from the French Ministry of Ecology, pp.32. Available at: http://www.observatoireclimat-hautsdefrance.org/Lesressources/Ressources-documentaires/Catalogue-des-indicateurs-du-changement-climatique Accessed 29 Jul 2020 
Parmesan C, Ryrholm N, Stefanescu C et al (1999) Poleward shifts in geographical ranges of butterfly species associated with regional warming. Nature 399:579-583. https://doi.org/10.1038/21181

Parmesan C, Root TL, Willig MR (2000) Impacts of Extreme Weather and Climate on Terrestrial Biota. Bull Amer Meteor Soc 81:443-450. https://doi.org/10.1175/15200477(2000)081\%3C0443:IOEWAC\%3E2.3.CO;2

Parmesan C, Yohe G (2003) A globally coherent fingerprint of climate change impacts across natural systems. Nature 421:37-42. https://doi.org/10.1038/nature01286

Peterson TC (2005) Climate Change Indices. World Meteorological Organization Bulletin 54: 83-86. Available at: http://etccdi.pacificclimate.org/papers/WMO.Bulletin.April.2005.indices.pdf Accessed 29 Jul 2020

Pounds JA, Fogden MPL, Campbell JH (1999) Biological response to climate change on a tropical mountain. Nature 398:611-615. https://doi.org/10.1038/19297

R Core Team (2018) R: A language and environment for statistical computing. R Foundation for Statistical Computing, Vienna, Austria. URL https://www.R-project.org/

Raffa KF, Aukema BH, Bentz BJ et al (2008) Cross-scale Drivers of Natural Disturbances Prone to Anthropogenic Amplification: The Dynamics of Bark Beetle Eruptions. BioScience 58:501-517. https://doi.org/10.1641/B580607

Raffa KF, Aukema BH, Bentz BJ et al (2015) Responses of tree-killing bark beetles to a changing climate. In: Climate change and insect pests (editors: C. Björkman, P. Niemelä). CAB International, vol 7. pp 173-201

Rebaudo F, Rabhi V-B (2018) Modeling temperature-dependent development rate and phenology in insects: review of major developments, challenges, and future directions. Entomol Exp Appl 166:607-617. https://doi.org/10.1111/eea.12693

Régnière J, St-Amant R, Duval P (2012) Predicting insect distributions under climate change from physiological responses: spruce budworm as an example. Biol Invasions 14:1571-1586. https://doi.org/10.1007/s10530-010-9918-1

Rive JL (1966) La processionnaire du pin, notions de biologie et principes de lutte. Note Technique $\mathrm{N}^{\circ} 5$, pp. 8.

Robinet C, Baier P, Pennerstorfer J et al (2007) Modelling the effects of climate change on the potential feeding activity of Thaumetopoea pityocampa (Den. \& Schiff.) (Lep., Notodontidae) in France. Global Ecol Biogeogr 16:460-471. https://doi.org/10.1111/j.1466-8238.2006.00302.x

Robinet C, Roques A (2010) Direct impacts of recent climate warming on insect populations. Integr Zool 5:132-142. https://doi.org/10.1111/j.1749-4877.2010.00196.x 
Robinet C, Rousselet J, Pineau P et al (2013) Are heat waves susceptible to mitigate the expansion of a species progressing with global warming? Ecol Evol 3:2947-2957. https://doi.org/10.1002/ece3.690

Robinet C, Laparie M, Rousselet J (2015) Looking Beyond the Large Scale Effects of Global Change: Local Phenologies Can Result in Critical Heterogeneity in the Pine Processionary Moth. Front Physiol 6:334. https://doi.org/10.3389/fphys.2015.00334

Rocha S, Kerdelhué C, Ben Jamaa ML et al (2017) Effect of heat waves on embryo mortality in the pine processionary moth. Bull Entomol Res 107:583-591. https://doi.org/10.1017/S0007485317000104

Roques A (2015) Processionary moths and climate change: an update. Springer, Dordrecht / Quae Editions, pp. 427. https://doi.org/10.1007/978-94-017-9340-7

Roques A, Rousselet J, Avci M et al. (2015) Climate Warming and Past and Present Distribution of the Processionary Moths (Thaumetopoea spp.) in Europe, Asia Minor and North Africa. In: Roques A. (eds) Processionary Moths and Climate Change : An Update. Springer, Dordrecht, pp.81-161. https://doi.org/10.1007/978-94-017-9340-7 3

Rosenzweig C, Casassa G, Karoly DJ et al (2007) Assessment of observed changes and responses in natural and managed systems. Climate Change 2007: Impacts, Adaptation and Vulnerability. Contribution of Working Group II to the Fourth Assessment Report of the Intergovernmental Panel on Climate Change, M.L. Parry, O.F. Canziani, J.P. Palutikof, P.J. van der Linden and C.E. Hanson, Eds., Cambridge University Press, Cambridge, UK, pp.79-131. Available at: https://www.ipcc.ch/report/ar4/wg2/historical-overview-of-climate-change-science/ Accessed 29 Jul 2020

Rossi J-P, Garcia J, Roques A, Rousselet J (2016) Trees outside forests in agricultural landscapes: spatial distribution and impact on habitat connectivity for forest organisms. Landscape Ecol 31:243-254. https://doi.org/10.1007/s10980-015-0239-8

Rousselet J, Imbert CE, Dekri A et al. (2013) Assessing species distribution using Google Street View: a pilot study with the Pine Processionary Moth. PLoS One 8:e74918. https://doi.org/10.1371/journal.pone.0074918

Rozenberg P, Pâques L, Huard F, Roques A (2020) Direct and Indirect Analysis of the Elevational Shift of Larch Budmoth Outbreaks Along an Elevation Gradient. Front For Glob Change $3: 86$. https://doi.org/10.3389/ffgc.2020.00086

Santos H, Paiva MR, Tavares C et al (2011) Temperature niche shift observed in a Lepidoptera population under allochronic divergence. J Evol Biol 24:1897-1905. https://doi.org/10.1111/j.1420-9101.2011.02318.x 
643

644

645

646

647

648

649

650

651

652

653

654

655

656

657

658

659

660

661

662

663

664

665

666

667

668

669

670

671

672

Shuttle Radar Topography Mission (SRTM) Non-Void Filled (Digital Object Identifier (DOI) number: /10.5066/F7K072R7)

Thomas CD, Lennon JJ (1999) Birds extend their ranges northwards. Nature 399:213. https://doi.org/10.1038/20335

Thomas CD, Cameron A, Green RE et al. (2004) Extinction risk from climate change. Nature 427:145148. https://doi.org/10.1038/nature02121

Tsankov G, Schmidt GH, Mirchev P (1996) Structure and parasitism of egg-batches of a processionary moth population different from Thaumetopoea pityocampa (Den. \& Schiff.) (Lep. Thaumetopoeidae) found in Bulgaria. Bollettino di Zoologia agraria e di Bachiccoltura, Ser. II, $28: 195-207$. Available at : https://www.researchgate.net/publication/259622330 Structure and parasitism of eggbatches of a processionary moth population different from Thaumetopoea pityocampa Den Schiff Lep Thaumetopoeidae found in Bulgaria. Accessed 29 Jul 2020

Urban MC (2015) Accelerating extinction risk from climate change. Science 348:571-573. https://doi.org/10.1126/science.aaa4984

Verner D, Wilby R, Breisinger C et al (2013) Tunisia in a Changing Climate: Assessment and Actions for Increased Resilience and Development. The World Bank, Washington, DC. https://doi.org/10.1596/978-0-8213-9857-9 Available at: http://documents.worldbank.org/curated/en/989681468313213278/Tunisia-in-a-changingclimate-assessment-and-actions-for-increased-resilience-and-development. Accessed 29 Jul 2020

Vicente-Serrano SM, Lasanta T, Gracia C (2010) Aridification determines changes in forest growth in Pinus halepensis forests under semiarid Mediterranean climate conditions. Agr Forest Meteorol 150:614-628. https://doi.org/10.1016/j.agrformet.2010.02.002

Walther G-R, Post E, Convey P et al (2002) Ecological responses to recent climate change. Nature 416:389-395. https://doi.org/10.1038/416389a

Zhang X, Yang F (2004) RClimDex 1.0: User Manual. Climate Research Branch Environment. Downs view, Ontario, Canada, 23p. Available at: http://etccdi.pacificclimate.org/software.shtml. Accessed $29 \mathrm{Jul} 2020$ 


\section{Declarations}

\section{$674 \quad$ Funding}

675 This study was supported by funding from the University of Carthage (Tunisia): the University

676 provided two grants to Asma BOUROUGAAOUI to spend her internships (two months/grant) at

677 INRAE-URZF in France in 2018 and 2019 in the frame of her PhD. It was also supported by the ANR

678 project PHENEC (grant number 19-CE32-0007-01).

679

680 Conflicts of interest/Competing interests

681 The authors declare no conflicts of interest.

682

\section{Availability of data and material}

684 Most of the datasets are provided in the article and supplementary material. Other datasets are 685 available from the corresponding author on request.

686

687

\section{Code availability}

688

The $\mathrm{R}$ code of analyses is available from the corresponding author on request.

689

690

Authors' contributions

691

$C R$ and $M B J$ designed the study. $A B$ conducted the field experiments, the laboratory analysis and the

692

statistical analyses; $C R$ and $M B J$ supervised her work. $A B, M B J$ and $C R$ wrote and revised the article.

693

694

\section{Ethics approval}

695 This study was conducted on an insect species (the pine processionary moth, Thaumetopoea

696 pityocampa), which is a pest species commonly controlled. In addition, this is a model species for

697 science which has been exempted from any declaration regarding the Nagoya protocole.

698

699 Consent to participate

700 Not applicable.

701

702

Consent for publication

703

The authors of this article consent to publish the study. 

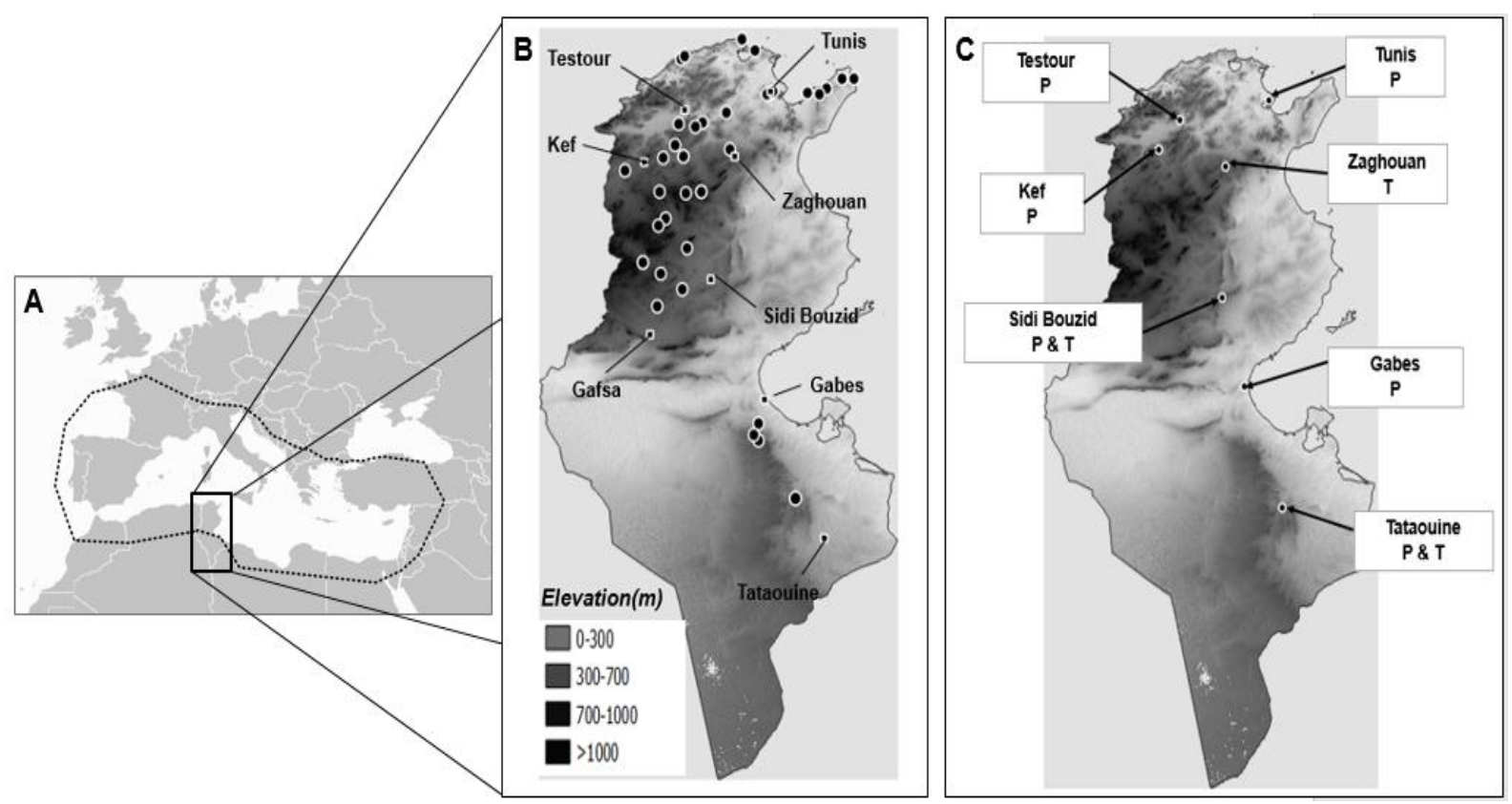

Fig. 1: (A) The rough distribution of the PPM across its range represented by the dashed line (derived from Roques et al., 2015), (B) the historical occurrence of the PPM in Tunisia (elevation background experiments on egg-masses $(T)$ across a latitudinal gradient in Tunisia. 


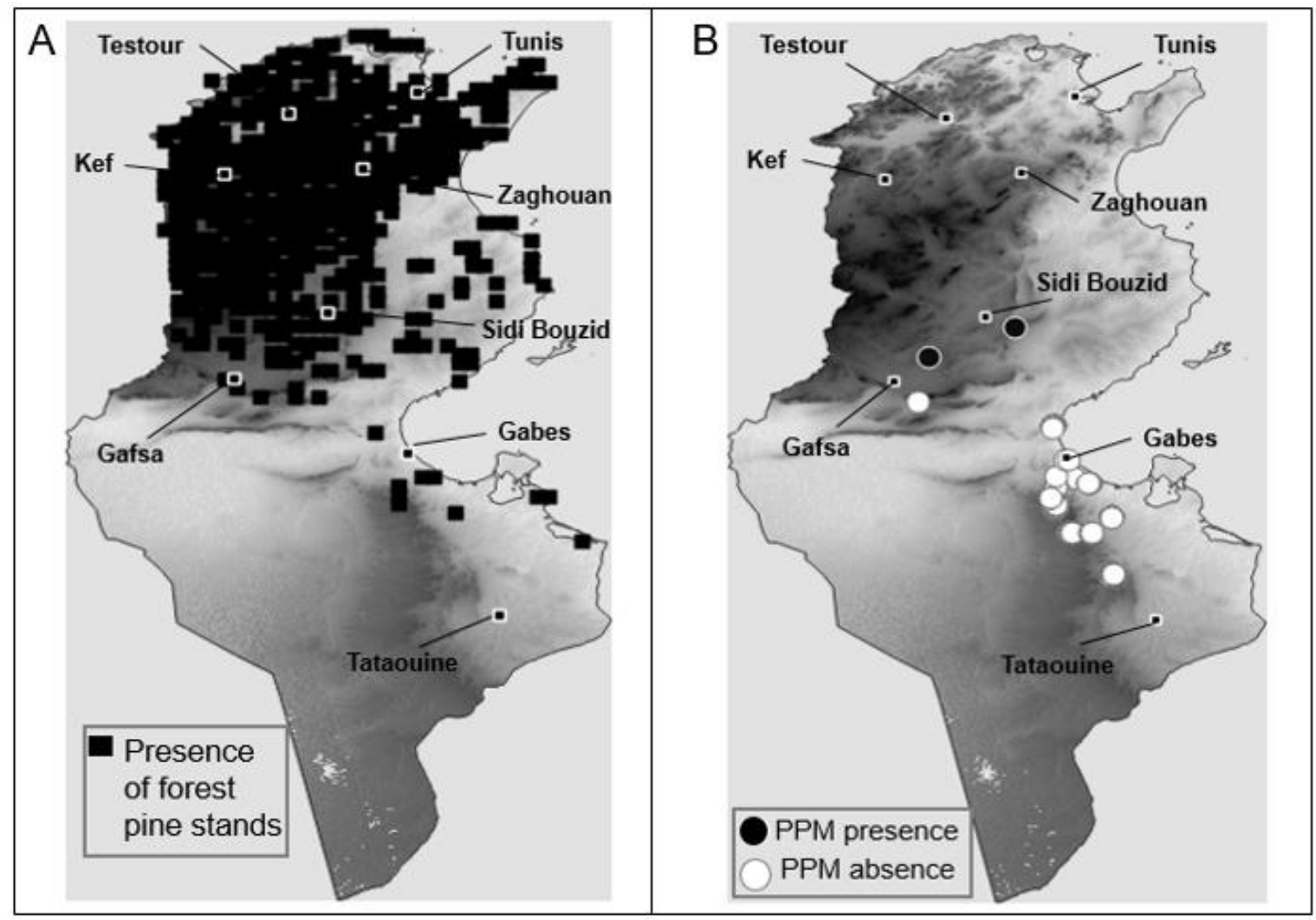

723

724 Fig. 2: (A) Map of forest pine stands on the $8 \mathrm{~km} \times 8 \mathrm{~km}$ grid, as reported by the General Direction of 725 Forests in Tunis, and (B) map of the PPM presence and absence in South Tunisia. 


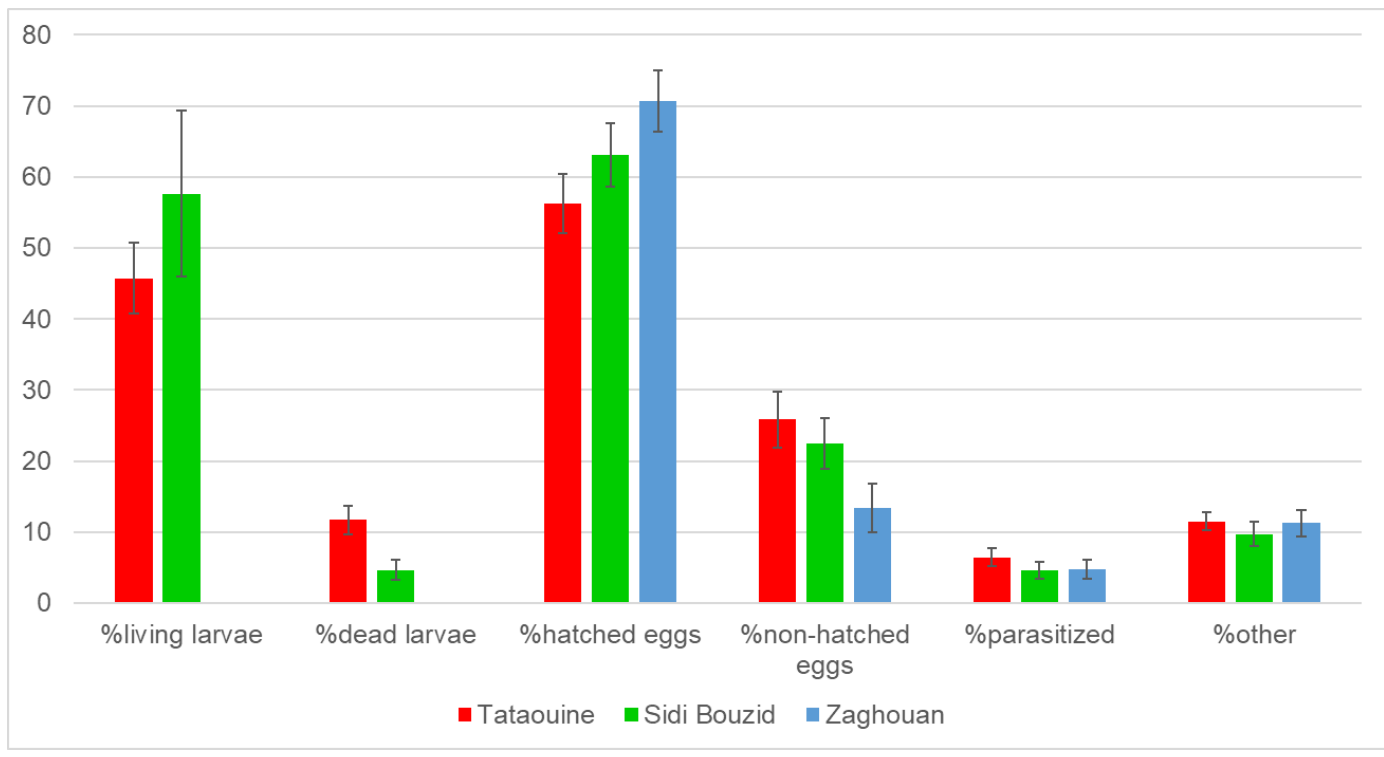

Fig. 3: Comparison of larval survival, egg hatching, parasitized eggs and other causes of egg mortality along the latitudinal gradient going from Zaghouan (within the PPM core distribution in North 731 Tunisia), Sidi Bouzid (the southern PPM limit) and Tataouine (region of disappearance in South Tunisia). Error bars indicate the standard error.

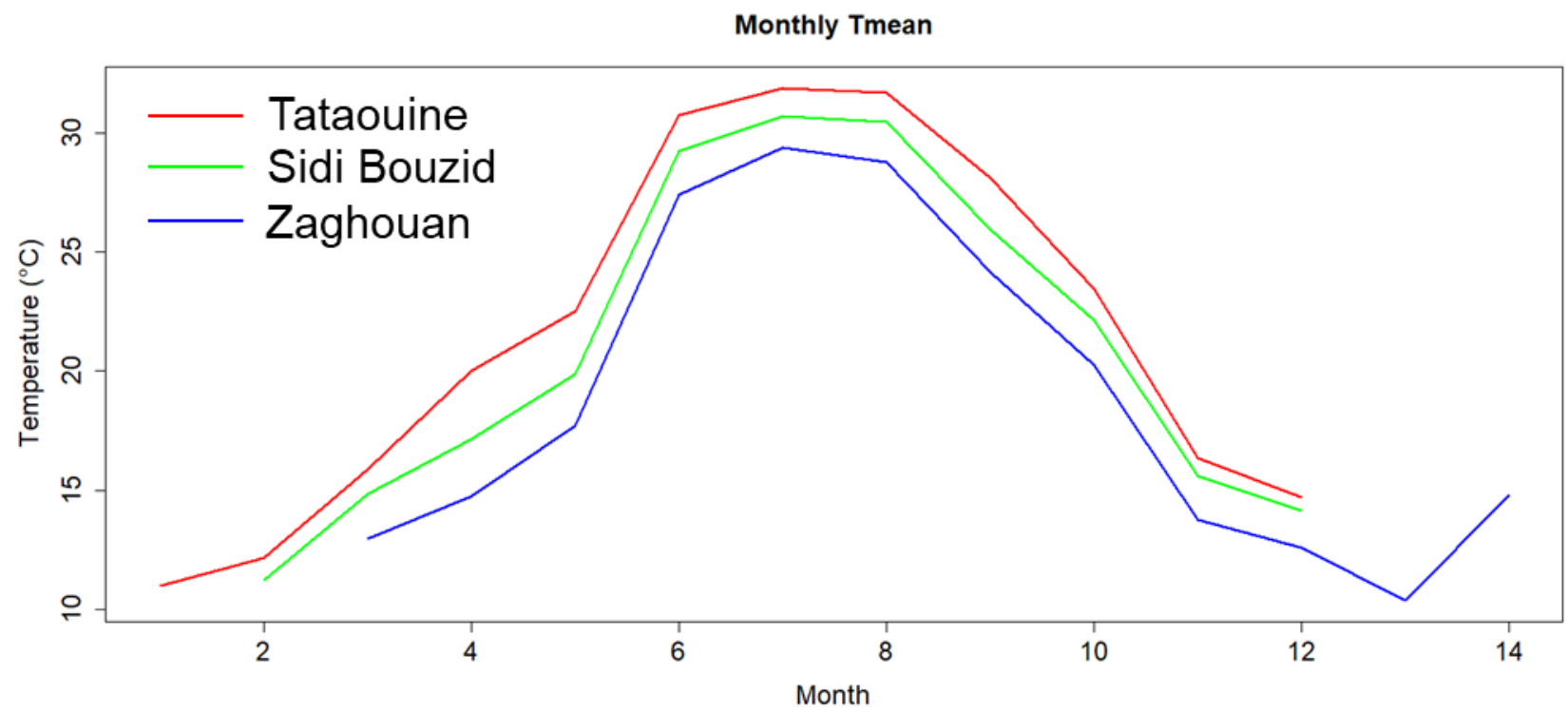

Fig. 4: Comparison of monthly mean temperatures in Tataouine, Sidi Bouzid and Zaghouan between January 2019 (month 1) and February 2020 (month 14) following data loggers installed on field sites. 

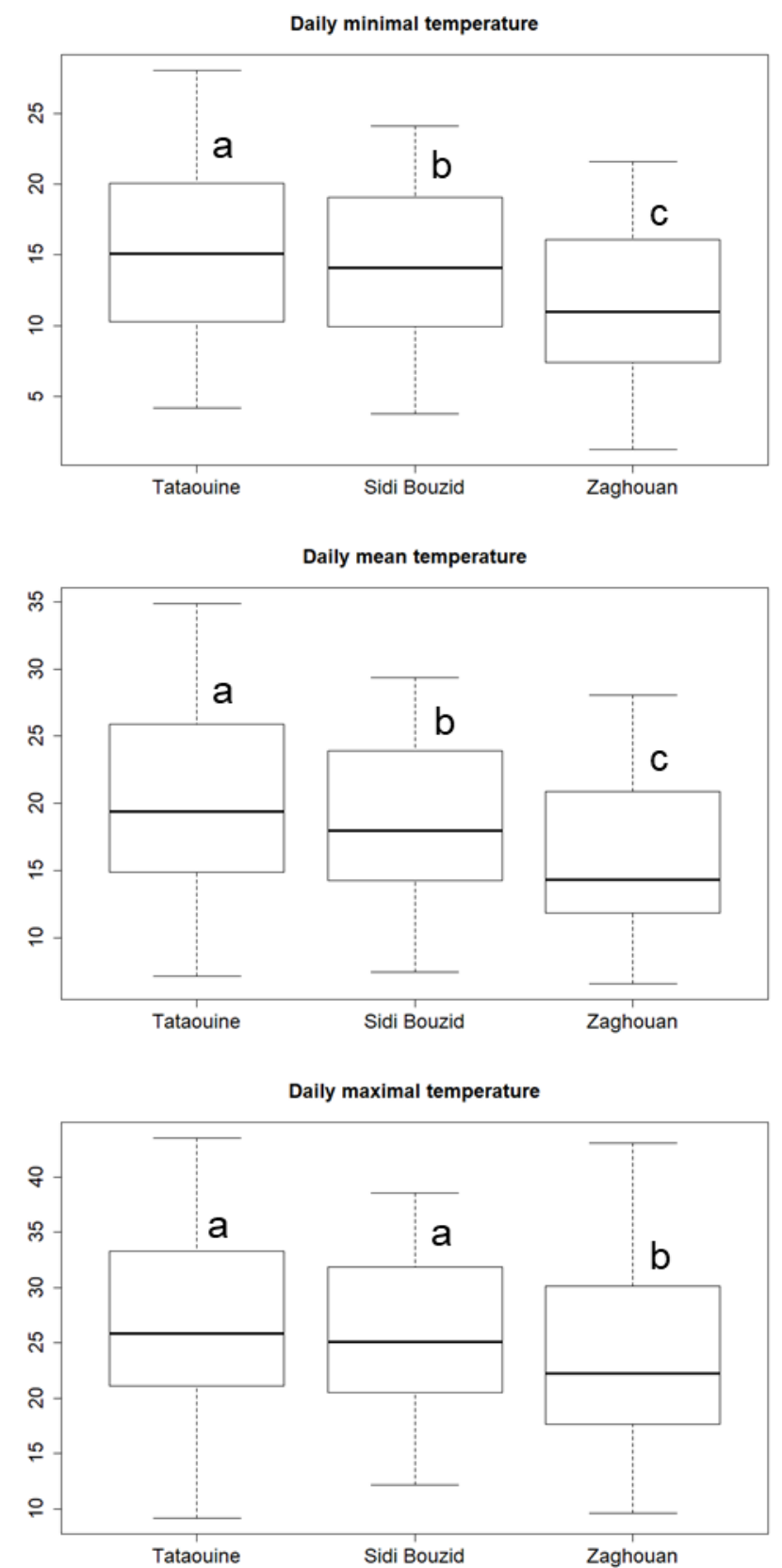

738 Fig. 5: Boxplot of daily minimal, mean and maximal temperatures recorded on sites from Sept $1^{\text {st }}$ 7392019 to Feb $5^{\text {th }}$ 2020. Different letters on each panel indicate a statistical difference using a pairwise 740 Wilcoxon Signed Rank Test. 
(a) Annual Tmin

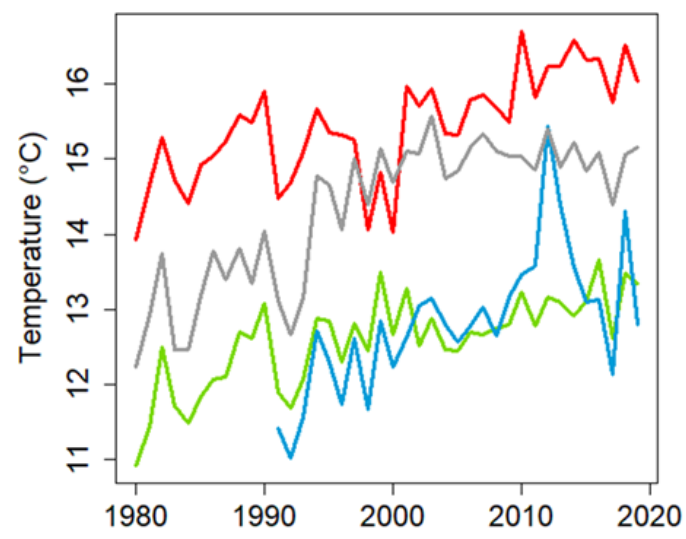

(c) Annual Tmean

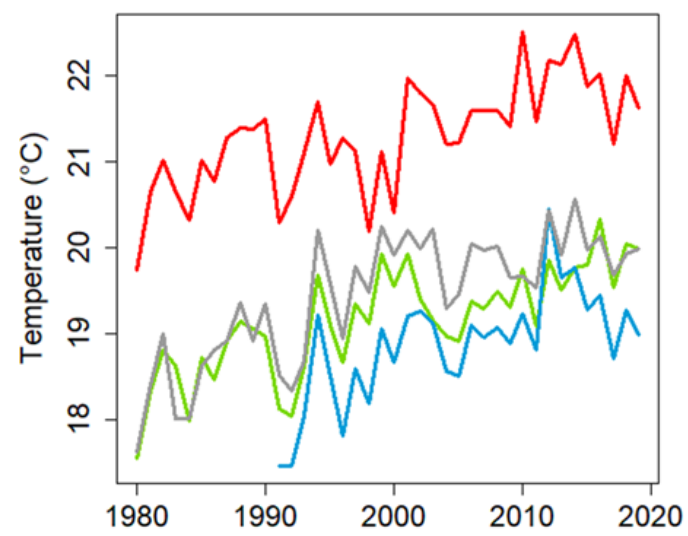

(b) Annual Tmax
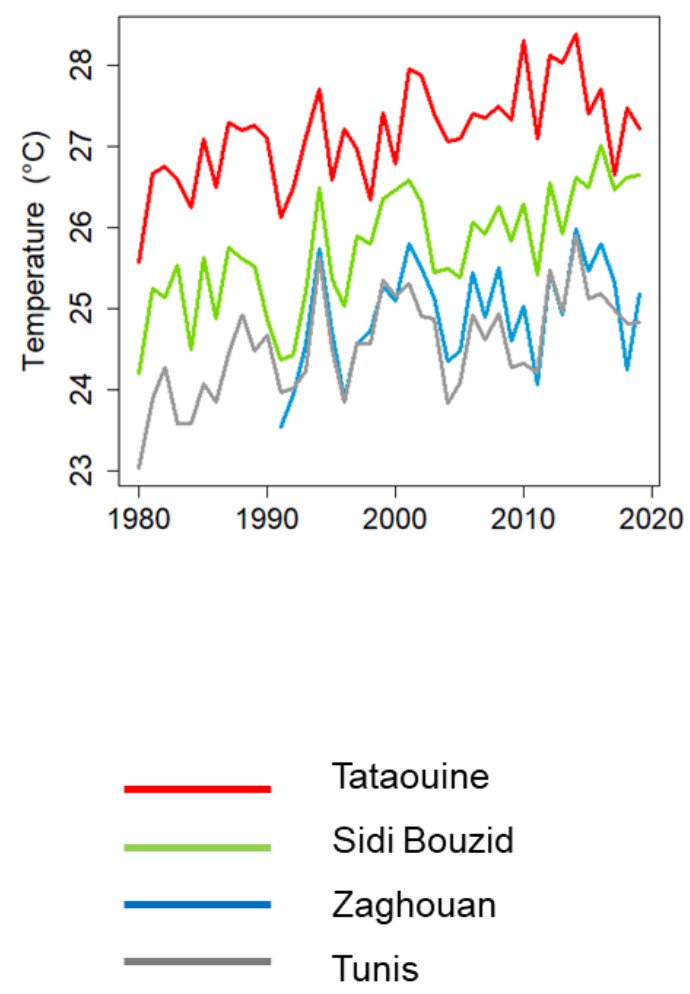

741

742

743 Fig. 6: Annual mean of daily (a) minimal, (b) maximal, and (c) mean temperatures on a south-north 744 gradient (going from Tataouine, Sidi Bouzid, Zaghouan to Tunis) between 1980 and 2019. 


\section{Tables}

\begin{tabular}{|l|l|l|l|}
\hline Index & Description & Definition & Units \\
\hline SU40 & Very hot days & Annual count when TX (daily maximum) $>40^{\circ} \mathrm{C}$ & days \\
\hline SU35 & Very hot days & Annual count when TX (daily maximum) $>35^{\circ} \mathrm{C}$ & days \\
\hline SU25 & Summer days & Annual count when TX (daily maximum) $>25^{\circ} \mathrm{C}$ & days \\
\hline TXx & Max Tmax: hottest day & Annual maximum value of daily maximum temp & ${ }^{\circ} \mathrm{C}$ \\
\hline TNx & Max Tmin: hottest night & Annual maximum value of daily minimum temp & ${ }^{\circ} \mathrm{C}$ \\
\hline TR25 & Tropical Nights & Annual count when TN (daily minimum) $>20^{\circ} \mathrm{C}$ & days \\
\hline TX90p & Warm days frequency & Percentage of days when TX $>90^{\text {th }}$ percentile & $\%$ \\
\hline TN90p & Warm nights frequency & Percentage of days when TN $>90^{\text {th }}$ percentile & $\%$ \\
\hline DTR & Diurnal temperature range & Monthly mean difference between TX and TN & ${ }^{\circ} \mathrm{C}$ \\
\hline
\end{tabular}

Table 1: List of extreme temperature indices used in this study.

\begin{tabular}{|c|c|c|c|c|c|}
\hline Gradient & Site & Installation date & Removal date & $\begin{array}{c}\text { Number of } \\
\text { traps }\end{array}$ & $\begin{array}{c}\text { Number of captures } \\
\text { (per trap) }\end{array}$ \\
\hline \multirow{4}{*}{ North Tunisia } & Tunis & June $28^{\text {th }}$ & Sept $28^{\text {th }}$ & 1 & $40(40)$ \\
\cline { 2 - 6 } & Testour & July $4^{\text {th }}$ & Oct $16^{\text {th }}$ & 3 & $167(56)$ \\
\cline { 2 - 6 } & Kef & July $3^{\text {rd }}$ & Oct $16^{\text {th }}$ & 3 & $173(58)$ \\
\cline { 2 - 6 } & Sidi Bouzid & June $19^{\text {th }}$ & Oct $24^{\text {th }}$ & 3 & $148(49)$ \\
\cline { 2 - 6 } & Gabes & July $31^{\text {st }}$ & Oct $24^{\text {th }}$ & 1 & $0(0)$ \\
\cline { 2 - 6 } South Tunisia & Tataouine & July $31^{\text {st }}$ & Oct $24^{\text {th }}$ & 3 & $0(0)$ \\
\hline
\end{tabular}

Table 2: Trap captures in summer 2018 along the latitudinal gradient in Tunisia. 


\begin{tabular}{|c|c|c|c|c|c|c|}
\hline \multirow{2}{*}{ Location } & \multicolumn{2}{|c|}{ Tmin } & \multicolumn{2}{c|}{ Tmax } & \multicolumn{2}{c|}{ Tmean } \\
\cline { 2 - 7 } & Slope \pm SE & $P$ & Slope \pm SE & $\boldsymbol{P}$ & Slope \pm SE & $\boldsymbol{P}$ \\
\hline Tunis & $0.067 \pm 0.008$ & $<0.001$ & $0.031 \pm 0.006$ & $<0.001$ & $0.048 \pm 0.006$ & $<0.001$ \\
\hline Zaghouan & $0.073 \pm 0.015$ & $<0.001$ & $0.029 \pm 0.013$ & 0.03 & $0.051 \pm 0.01$ & $<0.001$ \\
\hline Sidi Bouzid & $0.039 \pm 0.005$ & $<0.001$ & $0.044 \pm 0.006$ & $<0.001$ & $0.041 \pm 0.005$ & $<0.001$ \\
\hline Tataouine & $0.043 \pm 0.006$ & $<0.001$ & $0.031 \pm 0.006$ & $<0.001$ & $0.037 \pm 0.006$ & $<0.001$ \\
\hline
\end{tabular}

754

755 Table 3: Analysis of temperature trend during 1980-2019 (except for Zaghouan: 1991-2019). The

756 slope ( \pm standard error, $\mathrm{SE}$ ), with its significance probability $(P)$, represents the trend (unit: ${ }^{\circ} \mathrm{C} /$ year). 


\begin{tabular}{|c|c|c|c|c|c|c|c|c|c|}
\hline Station & SU40 & SU35 & SU25 & TXx & TNx & TR25 & TX90p & TN90p & DTR \\
\hline Tunis & 0.044 & $0.429^{* *}$ & $0.457^{* *}$ & 0.017 & $0.075^{* *}$ & $0.233^{* *}$ & $0.114^{*}$ & $0.318^{* *}$ & $-0.035^{* *}$ \\
\hline Zaghouan & -0.044 & -0.082 & 0.345 & -0.062 & $0.097^{*}$ & $0.222^{* *}$ & 0.072 & $0.426^{* *}$ & $-0.044^{*}$ \\
\hline Sidi Bouzid & $0.221^{*}$ & $0.712^{* *}$ & $0.601 * *$ & $0.048^{*}$ & $0.097^{* *}$ & $0.100^{*}$ & $0.164^{* *}$ & $0.228^{* *}$ & 0.005 \\
\hline Tataouine & $0.200^{*}$ & $0.520^{* *}$ & $0.448^{*}$ & 0.022 & $0.066^{* *}$ & $0.553^{* *}$ & 0.086 & $0.226^{* *}$ & $-0.021^{*}$ \\
\hline
\end{tabular}

Table 4: Decadal trends of the extreme indices of temperatures along four stations in Tunisia. For Zaghouan, we considered missing values between 1980 and 1990 to conduct the same decadal analysis. * indicates significance at $5 \%$ level $(P<0.05)$ and $* *$ significance at $1 \%$ level $(P<0.01)$. 
